\title{
Queensland Protects Sea Turtles
}

\author{
By H. Robert Bustard
}

In 1968 the Queensland Government gave five species of turtle full protection along the State's entire 3200-mile-long coast and the whole of the Great Barrier Reef. In this article Dr Bustard tells the history of turtle protection in Queensland and describes the two turtle population studies he has been running since 1964 which, with other studies, led to the protection order.

$\mathbf{O}$ N JULY 18th 1968 the Government of the State of Queensland, by Order in Council, 'prohibited the taking of any species of turtle in all Queensland waters and on or from the foreshore of or in any such waters and the taking of the eggs of any species of turtle in all Queensland waters and on or from the foreshore of or in any such waters'. This means that five species of sea turtles are totally protected along a coastline of 2500 miles and also along 1200 miles of the Great Barrier Reef; the State of Queensland includes the islands in Torres Strait and extends right up to the Papuan coast. This is by far the most important conservation legislation passed for sea turtles anywhere in the world, and the gigantic area covered by the order guarantees the future of very large populations of green turtle Chelonia mydas, loggerhead Caretta caretta, hawksbill Eretmochelys imbricata, flatback Chelonia depressa, and leathery turtle Dermochelys coriacea. In Queensland there are important rookeries for all these turtles except the leathery; as much of the northern coast is unexplored it is quite likely that this too will be discovered nesting.

It is interesting to trace the development of this legislation. In summer 1929-30 F. W. Moorhouse, a Queensland Government Fisheries Officer studying green turtles on Heron Island, where a turtle soup cannery was operating, was disturbed by the wasteful exploitation of female turtles which were 'turned' on the beach before they had a chance to lay their eggs, and recommended that the green turtle be conserved. He pointed out that a close season during the early part of the nesting season would allow several clutches of eggs to be laid before the female turtles were killed. Subsequently the Queensland Government imposed a close season in October and November. (Turtles start nesting in the Capricorn Group of islands at the southern end of the Great Barrier Reef in the last week of October, and clutches, which average 110 eggs, are laid at 15-day intervals.) Moorhouse's pioneer study influenced subsequent workers including Tom Harrisson in his large-scale work on the controlled exploitation of green turtle eggs in Sarawak, and his work in turn greatly influenced me.

In 1950, following a campaign by F. McNeill of the Australian Museum, the Great Barrier Reef Committee, and others, the green turtle was totally protected in Queensland south of Cooktown $\left(15^{\circ} \mathrm{S}\right)$ about one half of the coast - which was a great advance. However, green turtles migrate very great distances (of the order of 1000 miles) to their nesting beaches so that they could still be legally fished when they moved north after laying. The 1950 recommendations were for an investigation into the ecological and economic status of the green turtle along the Great Barrier 
Reef, pending which the green turtle should be placed on the list of protected animals. However, no research was carried out on the green turtle until, in 1964, I visited Heron Island at the southern end of the Great Barrier Reef and initiated a study of the population ecology of Queensland green and loggerhead sea turtles.

All the adult female turtles nesting on Heron Island are tagged, after laying their eggs, by means of a monel metal tag (invented by Tom Harrisson) fixed to the trailing edge of the left front flipper (see opposite); some on nearby islands were also tagged. On Heron Island information is kept on all nesting turtles throughout a 15 -week period each summer, including clutch size and incubation success, and we have had recaptures from as far away as Papua-New Guinea and New Caledonia. For three years we operated a 50,000-egg capacity hatchery (opposite) and marked large numbers of hatchling turtles for growth studies. The research, now in its fifth year and still in progress, is an excellent example of conservation work in practice. Every summer thousands of people visit the island, watch our work and learn of our aims.

In February 1968 as a result of preliminary data collected in the first four years, I requested the Government to extend protection to all sea turtles, and if possible extend the legislation to the whole State. This recommendation was supported by the Great Barrier Reef Committee and other interested bodies, including the Wildlife Preservation Society of Queensland. The result was the Order in Council already quoted.

Properly exploited, sea turtles and/or their eggs could be a valuable continuing source of protein; unfortunately, exploitation is frequently extremely short-sighted. Europeans usually take turtles on the beaches at the start of the breeding season before the female turtle has even laid her eggs. As green turtles nest about every three years, a three-years' crop of up to about 1000 eggs is wasted. Furthermore the male turtles remain an untapped resource whilst the females are greatly overfished. Schemes like Tom Harrisson's in Sarawak, which utilise only the eggs, are much better. However, these may suffer from not enough eggs being protected and allowed to hatch. At least 10 per cent of the eggs laid should be protected from predators, and the hatchlings liberated in deep water over the edge of the reef. Many reptile eggs are very susceptible to movement even when freshly laid, and collecting and moving them to an adjacent hatchery, even using great care, results in a lower percentage hatch. It is, of course, much more practical to move eggs to a central hatchery than to construct enclosures around individual nests. However, if the eggs are moved in order to protect them, then the proportion protected should be increased to a minimum of 15 per cent, the remainder being available for human consumption.

The new legislation in Queensland alters the conservation problems of many sea turtles, but the leathery turtle, unless an important rookery is found in Queensland or elsewhere in northern Australia, has the least certain future of the world's sea turtles. Every effort must be made to increase substantially the percentage of the leathery turtle's eggs being protected in Malaya and to try again to start a hatchery scheme in Ceylon. 


\section{TURTLE RESEARCH}

\section{AREA}

PLEASE ASSIST BY NOT USING LIGHTS KEEP NEAR HIGHWATER MARK KEEP BEHIND NESTING TURTLES.

\section{AUSTRALIAN NATIONAL}

\section{UNIVERSITY.}
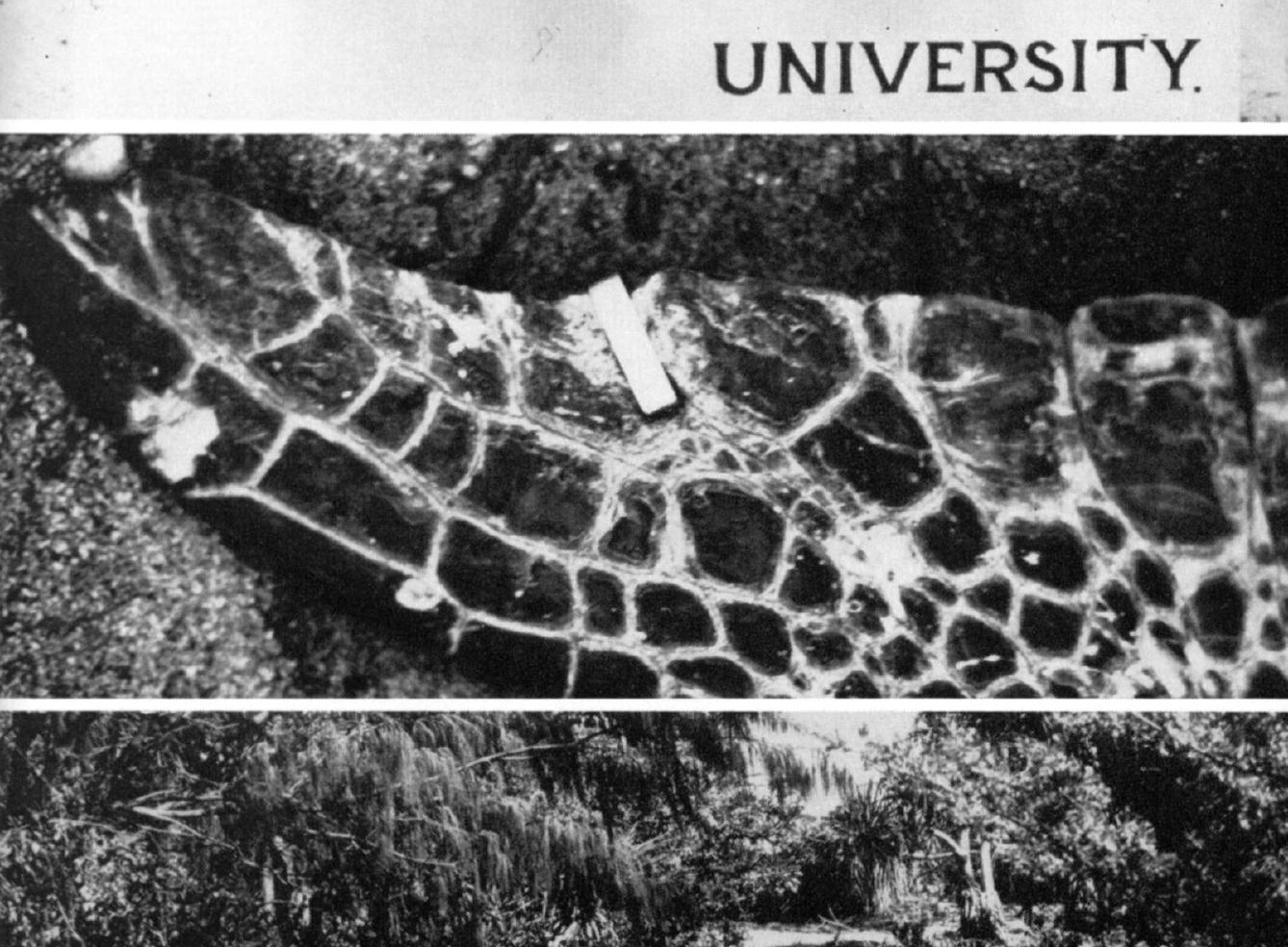

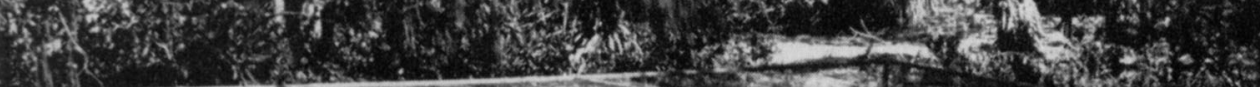

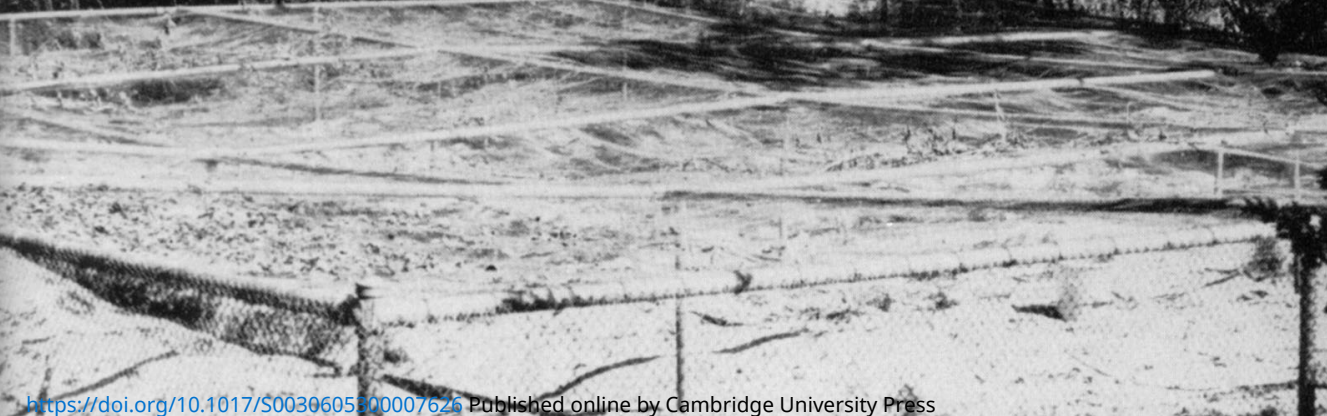

bafps:Hdoi.org/10.1017/\$0030605/6000/62 Pablished online by Cambridge University Press $120 \%$

(2.3.

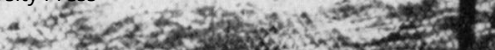





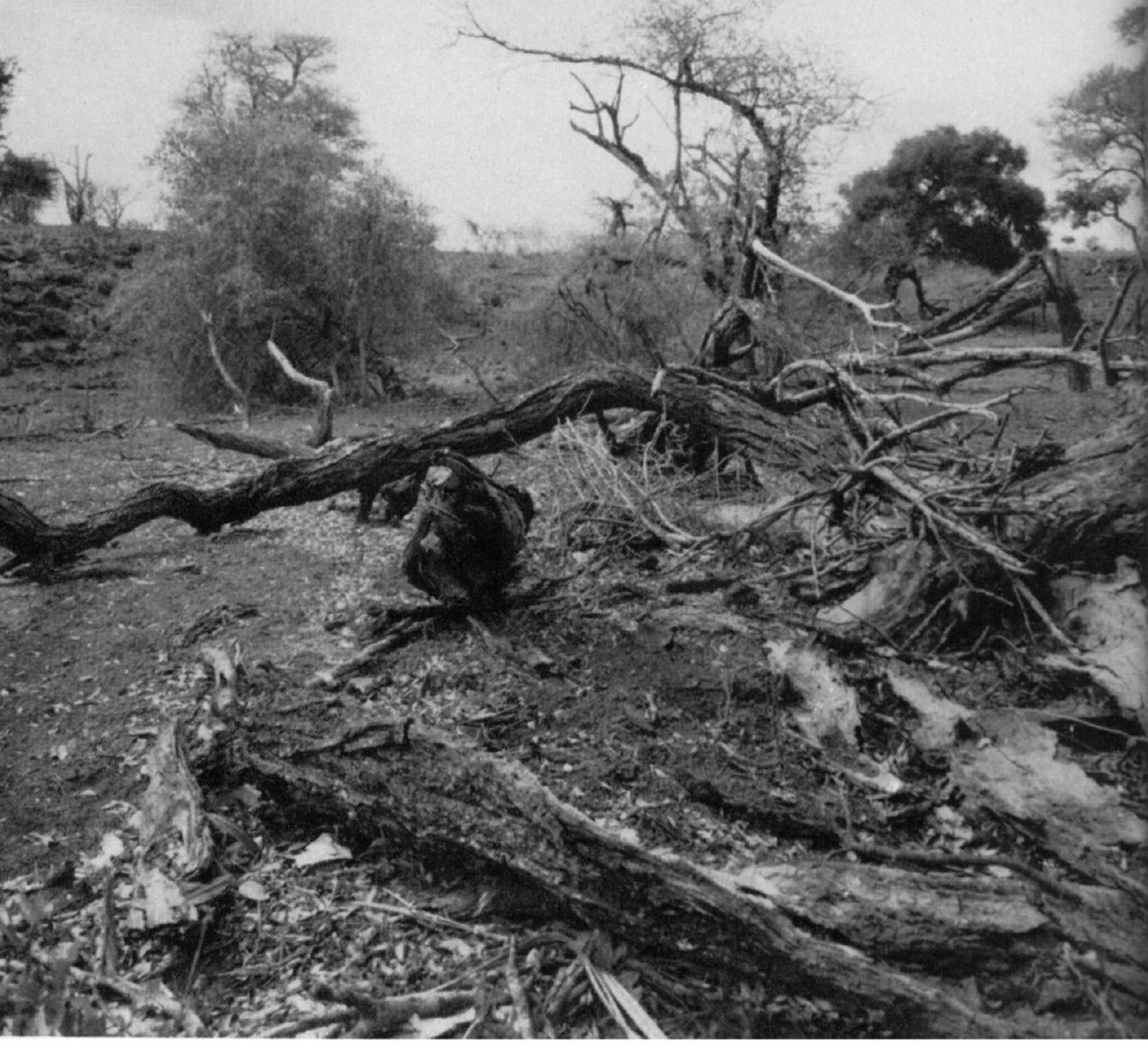

DEVASTATION IN RHODESIA: The Tuli Circle National Land in February 1966, with grasses and many shrubs destroyed and trees dying. Plate 4 